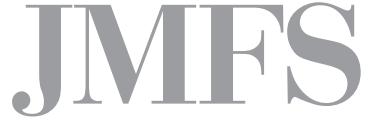

Journal of Management and Financial Sciences
Volume XI

Issue 31 (March 2018)

pp. 121-133

Warsaw School of Economics

Collegium of Management and Finance

Piotr Bartkowiak

Faculty of Management

Poznań University of Economics and Business

Ireneusz P. Rutkowski

Faculty of Management

Poznań University of Economics and Business

\title{
Implementation of the IMZD Approach (IMZD as the Integrative Maturity Capability Model) in the Performance of a New Product Process
}

ABSTRACT

The publication sets out to propose a new research approach - one that could significantly improve the maturity measurement of product innovation processes in businesses. As detailed here, the concept for measuring the maturity of an innovation and new product marketing process reflects a specific research attitude towards new product development. Importantly, too, the concept sees those approaches as guiding and directing the studies into the matrix- and grid-based methods, which are developed using new analytical tools. What is presented here is an overview of methodologies with their relevant techniques and procedural algorithms (methodology in a pragmatic sense).

Keywords: maturity of the process, innovations, product JEL Classification Codes: D81, O14, O31, O32 


\section{Introduction}

The product innovation process, identified here with the process of developing a new product (PRNP), crowned with market, financial and technological success, is difficult to achieve. Therefore, an enterprise should create an appropriate organization, which is a significant condition for effective management of the innovation process (even the best idea for a new product may not be successful if it is implemented by incompetent people, poorly organized and managed). The best practices, concepts, methods and analytical tools as well as networks of relations with various stakeholders should be used in each phase of this process.

The globalization processes in the economy and the increasing competition, also in the space of virtual markets, make it necessary to use better methods of managing the new product development process. Fundamental to the survival and development of a company is the delivery of new products that satisfy the individual needs of customers and successfully compete in the serviced segments of the market. It is important to reduce losses in limited resources - material losses, effort, money and time, and to guarantee continuous improvement of competences. The key elements of the new method of managing the product innovation process are the integration of development activities and the reduced time needed to bring the product to market. The integrated product development process (IPD-Integrated Product Development) is a concept strongly focused on the needs of customers as well as the company's competences and opportunities in its environment. Therefore, the aim of the study is to propose a method for measuring the maturity of the new product innovation process, so-called the maturity model of the intelligent relationship network.

Empirical research indicates that the success rate of major new product development (NPD) projects is still low [Crawford, 1979, pp. 9-13; Griffin 1997, pp. 429-458; Stevens, Burley, 1997, pp. 16-27; The PDMA, 2012; Cooper, Edgett, 2008; Rutkowski, 2007, pp. 77-92; Rutkowski, 2016, p. 215]. It is therefore no surprise that identifying and managing NPD have become increasingly important issues in the product innovation literature and practice [Cooper, 1993; Wheelwright, Clark, 1992; Wu et al., 2010; Walker, 2013].

Literature references about new product strategy, project management, success and failure factors in NPD, already have yielded important findings about critical issues within the new product development process (NPDP). However, for at least two reasons these references fail to provide a comprehensive picture of the security and risk factors involved with product development. First, a vast majority of these studies used survey methods across companies, involving only one person in each division or strategic business unit. Secondly, because most of these studies were retrospective, the events occurring late in the process have a bigger chance of being recognized as major determinants of the outcomes of NPD projects than the events earlier on.

The results also show that NPD performance is the highest when market (entrepreneurial) orientation, networking capability, and networking ability are all high, thus supporting the proposed three-way interaction [Mu et al., 2017, pp. 187-201]. 
R\&D, design, prototype construction, testing, marketing research are carried out before a new product is launched, and in many cases, a lot of new product development concepts do not even reach the commercialization phase. This means that a new product, whose development process has been successful and has been launched on the market, must provide not only the cost of its development, but also the reimbursement of expenditure on irrelevant ideas, concepts and prototypes [Pickshaus et al., 2016, pp. 265-270].

Generally, new product strategies constitute a huge investment for the enterprise and are related to managerial responsibility and permanent uncertainty and risk. [The PDMA, 2012]. The key to the success of introducing a new product is a solid and comprehensive understanding of the client's needs. Managing the development process of a new product requires measuring its maturity. Measuring the maturity of the innovation process and introducing a new product on the market and the network of relations, in addition to measuring the quality of design, costs, schedule, allows to determine the correctness of defining the process and compare it with the globally accepted starting criteria. Traditionally, the improvement of the new product development process was perceived through the prism of the implementation of the so-called best practices. This concept should be understood as a tactic or a method that has been successfully implemented in the course of the actual implementation of the product innovation process.

\section{Determinants of the maturity of the product innovation process}

To a large degree, the level of success a new product can make depends on the maturity of the product innovation and marketing process (process maturity is an extent to which the process is defined, managed, measured, controlled and effective in terms of project costs, implementation time, and project quality). The more mature the new product development process is, the more success a product will achieve on the market, and vice versa. The determinants of maturity in new product development are similar across different manufacturing firms and industries. New product development processes vary in terms of their complexity. This variation is strongly determined by the new product strategy and how advanced the product concept is in terms of technology. Complex processes with a low formalisation (found at all stages of the innovation process) are used in the development of new original products that become a new product platform (development of new components for the core product and of new elements around the existing product - absolute technical solutions). On the other hand, processes involved in the development of new derivative (imitative) products (changes around the actual and augmented products only - adaptive technical solutions) are relatively simplified and formalized, with low maturity levels [Rutkowski, 2007, pp. 77-92].

A number of threats to businesses and their target markets which came to light during the recent financial crisis, such as their instability or a dwindling trust in their self-regulating 
ability, have drawn attention of a variety of research, advisory or decision-making bodies. In response, these institutions have taken regulatory action to make the markets safer and to ensure sustainable growth [Bartkowiak, 2004, pp. 22-25]. These new business conditions will also have an impact on the way businesses organise their strategic and operational activities.

The success factors for a new product are related to whatever determines the maturity of the product innovation process (how well the organisation does what it does) and to the diffusion of best practices (how widespread a best practice is within the organisation, and how often the organisation relies on it). If a project team wants to achieve the objectives of its new product strategy (success), it must find an answer to two fundamental questions. The first is whether what we are doing is right (which means that only the best ideas, concepts, designs, or new product prototypes must be selected at later stages in the product innovation process, and that the product must be commercialised effectively). The other question is whether what we are doing is done in the right way (for that, the maturity level of the product innovation process must be known).

\section{Ways to assess the implementation level of best practices}

New product strategies should accommodate a number of factors, including highly dynamic and unpredictable technological and legal developments on the one hand, and demand, competition and competence, on the other [Trott, 2011, pp. 156-187]. When businesses operate in such conditions, it is reasonable to try and identify potential sources for the success of a new product on the market as the most important condition for the success of an organisation as a whole [Skrzypek, Hofman, 2010, pp. 37-46]. Questions that arise in this context are: What factors affect the maturity of the innovation and new product marketing process? Are there any relationships/correlations between what makes the innovation and new product marketing process mature and the success of a new product on the market? If there are, are they empirical and measurably verifiable, and if so, how significant are these relationships, and what is their direction, nature and hierarchy? Finally, what methods and tools are there to measure product innovation maturity accurately?

The extent or level to which a practice is implemented can be determined on a scale of $0-10$. Table 1 shows how model practices are appraised. Evidence is divided into three groups: direct artefacts, indirect artefacts, and affirmations. Direct artefacts are tangible outputs resulting directly from the implementation of a specific or generic model goal, and they are the most desirable products/outputs of a model practice. Indirect artefacts are a sort of a side effect or by-product resulting from the implementation of some specific or generic model goal, but they are not listed as desirable products/outputs of a model practice. Affirmations are oral or written statements confirming that a model practice has actually been implemented. Final appraisal findings are formulated based on earlier preliminary appraisal results and on any feedback received during the validation activity. Final findings are generated based on the 
appraisal of goals for each process area subject to an appraisal. Goals are rated in accordance with certain defined rules (Table 1).

Communication channels are used to transmit and disseminate best practices among entities involved in new product development. This is done over a certain period of time and how fast best practices are diffused will depend on the ability of the entity concerned (firm, organisational unit, or person) to learn, gather knowledge and use this knowledge in decision-making processes. The diffusion of best practices among firms describes how fast and to what extent such practices are adopted in an industry or within a group of similar businesses. The characteristics of best practice will determine both the pace of its adaptation and its level. A collection of best practices consists of subgroups and is continually updated. New best practices are identified to replace the current ones that became standard practices. A significant number of best practices is represented by specific activities in the different phases of the product innovation process [Rutkowski, 2007, p. 80].

Table 1. Model practice characterisation rules and principles

\begin{tabular}{|c|c|}
\hline Practice implementation level $(0-10)$ & Meaning - evidence (artefacts, affirmations) \\
\hline $\begin{array}{l}\text { Fully Implemented } \\
9 ; 10\end{array}$ & $\begin{array}{l}\text { - At least one direct artefact is present and judged to be adequate. } \\
\text { - A few indirect artefacts and/or affirmations exist. } \\
\text { - A practice is confirmed to be implemented and no weaknesses were noted. }\end{array}$ \\
\hline $\begin{array}{l}\text { Largely Implemented } \\
7 ; 8\end{array}$ & $\begin{array}{l}\text { - One direct artefact is present and judged to be adequate. } \\
\text { - At least one indirect artefact and/or affirmation exist. } \\
\text { - A practice is confirmed to be implemented and no weaknesses were noted. }\end{array}$ \\
\hline $\begin{array}{l}\text { Partially Implemented } \\
5 ; 6\end{array}$ & $\begin{array}{l}\text { - Direct artefacts are absent or judged to be inadequate. } \\
\text { - At least one indirect artefact or affirmation suggests that some aspects of the practice are } \\
\text { implemented, and one or more weaknesses were noted. }\end{array}$ \\
\hline $\begin{array}{l}\text { Not Implemented } \\
3 ; 4\end{array}$ & $\begin{array}{l}\text { - No other evidence supports the direct artefacts, and one or more weaknesses were } \\
\text { noted. }\end{array}$ \\
\hline $\begin{array}{l}\text { Not Yet } \\
0 ; 1 ; 2\end{array}$ & $\begin{array}{l}\text { - The project has not yet reached the appropriate stage in the innovation lifecycle to have } \\
\text { implemented the practice. }\end{array}$ \\
\hline Goal rating & Rules \\
\hline Not rated & $\begin{array}{l}\text { - There are any practices that are not characterized at the organizational unit level or that } \\
\text { are characterized as Not Yet at the organizational unit level. } \\
\text { - The associated set of objective evidence does not meet the defined criteria for sufficient } \\
\text { data coverage. }\end{array}$ \\
\hline Satisfied & $\begin{array}{l}\text { - All associated practices are characterized at the organizational unit level as either fully } \\
\text { implemented or largely implemented. } \\
\text { - The aggregation of weaknesses associated with the goal does not have a significant } \\
\text { negative impact on goal achievement. }\end{array}$ \\
\hline Unsatisfied & $\begin{array}{l}\text { - The appraisal team must describe how the weaknesses identified in the appraisal led } \\
\text { to this rating. }\end{array}$ \\
\hline
\end{tabular}

Source: Rutkowski, 2016, p. 215 based on: Chrapko, 2010, p. 265.

Managing the product innovation process is strongly related with measurements of its efficiency. Apart from measuring costs, schedules or design quality, process maturity measurements determine whether a process is properly defined and allow its comparison with global entry criteria, that is its maturity conditions. Traditionally, improvements to the new product 
development process were viewed in terms of best practices that were implemented in it. Generally, a practice is a selected tactic or a method used to perform a specific task and achieve certain goals. For example, team member selection is a practice which helps to determine the organisation's competences in terms of its ability to react quickly. In this perspective, a best practice should be understood as a tactic or method which has been successfully used when actually implementing the new product development process. The examples of best practices are as follows: using a multidisciplinary project team in the new product development process (NPD); using a development process that is structured and integrated; using an integrated set of development methods and tools (QFD - quality function deployment, rapid prototyping - modelling, simulation, portfolio management for new product projects).

\section{Assessment of the maturity of the product innovation process}

To an extent, a business receives a ready-made process improvement plan that only needs implementing. This is of benefit to those businesses that lack sufficient knowledge of their innovation processes and how advanced they are, and as such are unable to decide on their improvement plan. In such a situation, the staged representation can be very useful. This approach provides for different capability levels for the product innovation process within a business, as shown in figure 1.

Each maturity level of the product innovation process may also be seen as representing a specific process transparency level. The organisation that already has some knowledge of its product innovation process (has identified their strengths and weaknesses and knows what it would like to change/improve in them) may use what is offered by the continuous representation. This type of representation may be used to improve only those of the process areas that really need it. The continuous representation uses the concept of Capability Levels which an organisation may rely on to improve specific processes using a pre-defined scale. In this approach, we can accurately define capability levels for selected processes within a business that we would like to achieve.

A decision on what needs to be improved in a process, and on the extent of improvement, lies with a firm's management. At level 1 the process is seen as a "black box". At maturity level 2, the process is visible (can be captured) in some transitional periods separated by decision gates (in the integrated PHASE-GATE new product development process). At level 3, internal mechanisms become visible at each process stage.

Maturity level 4 is characterised by continuous process efficiency measurements, and the focus here is on improving activities at each stage in the new product development. At level 5, the process structure is improved on a continual basis [Paulk et al., 2011]. Figure 1 describes different maturity levels in new product development which a business must go through on 
its way to achieving the highest process maturity. ${ }^{1}$ As they apply to new product development, the different IMZD² CMM/CMMI maturity levels show significant differences.

\section{Figure 1. Detailed maturity appraisal criteria for the product innovation process}

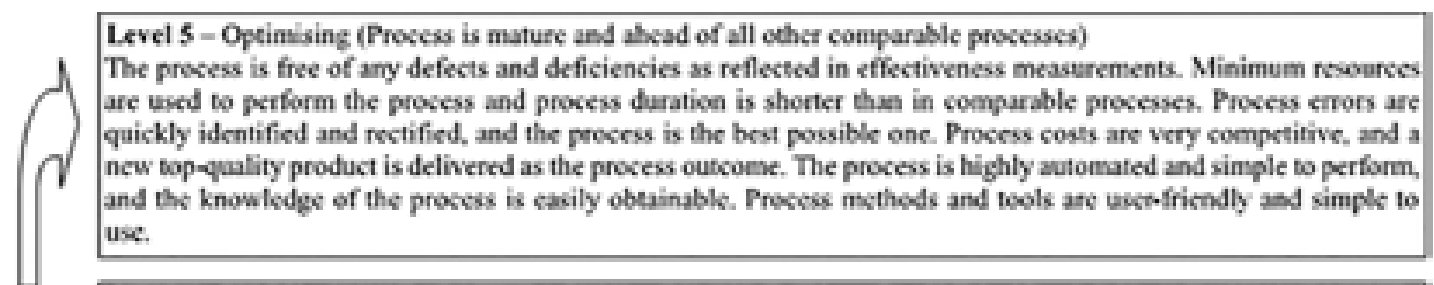

Level 4-Managed (Process is effective and free from defects and deficiencies)

Methods and technigues of aew product developeneat are efficient and proven. Required changes to development and prodaction are significantly reduced. The measures used show positive trends; the process is highly efficient. The peocess provides insight that can be used in formalsting a strategy which reflects custoencr expectations and the expected competitive and technological conditions. The process is compatible with ether business systems. The process is very effective and efficient (comparable to the best processes). Process tools, including instruction manuals, are exsily aceessed by all users. The process generates SIX SIGMA Quality products, with a standand deviation within $+i-6$ sigma.

Level 3 - Defined (Process is effective and efficient as per entry criteria)

Activities are concurrent and iaitiated as quickly as possible. Performers implement the process sanoothly and develop prodacts. Product development time is significantly reduccd. There is a signifieant reduction of new prodact development and production eosts. Process risks are defined and acceunted for. Customers and sappliens are elosely involved in the process. Benchmarking is used and the prosess is ranked within the top $10 \%$. Measures are used to document effects of prosess inprovements.

Level 2 - Repcatable (Process improvements are implemented and measured)

The proeess is easily adaptable to reflect custemer and peoject needs. Few adjustunent activities are feejuired to mect project requirements. All activities are focused en prejest implementation and delivery of reqaired information. The process is designed in such a way that users can quickly learn about potential new product applications. The process provides a clear description of activities, precconditions, expected results, competences, and process iechniques, methods and mechanisms. As inplemented, the process is substantially effective from the customer's point of view. Defects, fualts and deficiencies are quickly identified and their root causes isolated. Efficiency and perfoemance are detcrmincd against cussomer expectations, nceds and requirements. Mcasures are defined for continuous peocess improvencen.

\begin{tabular}{|c|}
\hline 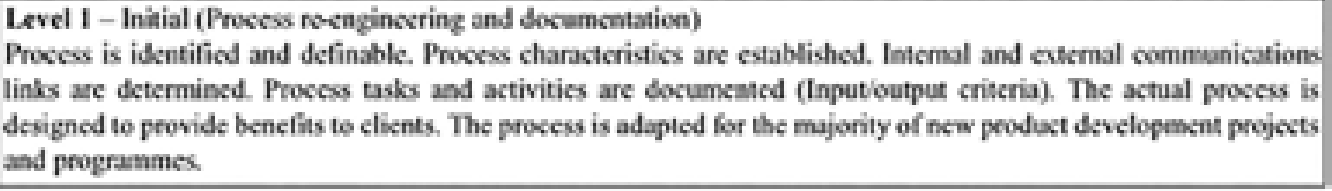 \\
\hline $\begin{array}{l}\text { Level } 0 \text { - Incemplete } \\
\text { In this proscss arca, all spccific practices that were cmvisagcd for the Ist level of maturity were not implcmented. }\end{array}$ \\
\hline
\end{tabular}

Source: the author's compilation: Capability, 2006; SCAMPI, 2011.

1 For example, Danish audit services firm Delta, which carries out CMM/CMMI-IPPD appraisals of software development companies, gave Intel Technology Poland, of Gdańsk (a member of the Intel Communication Group), a rating of 3.5. The ranking reflects the team's maturity and is a measure of its ability to deliver top-quality products on schedule. Globally, the average rating is 1.75. Ratings of 4 or higher assigned to firms in space and military industries.

2 Integrative Maturity Capability Model of the new product development process. 
Figure 2. Components of the Integrative Maturity Capability Model of PRNP

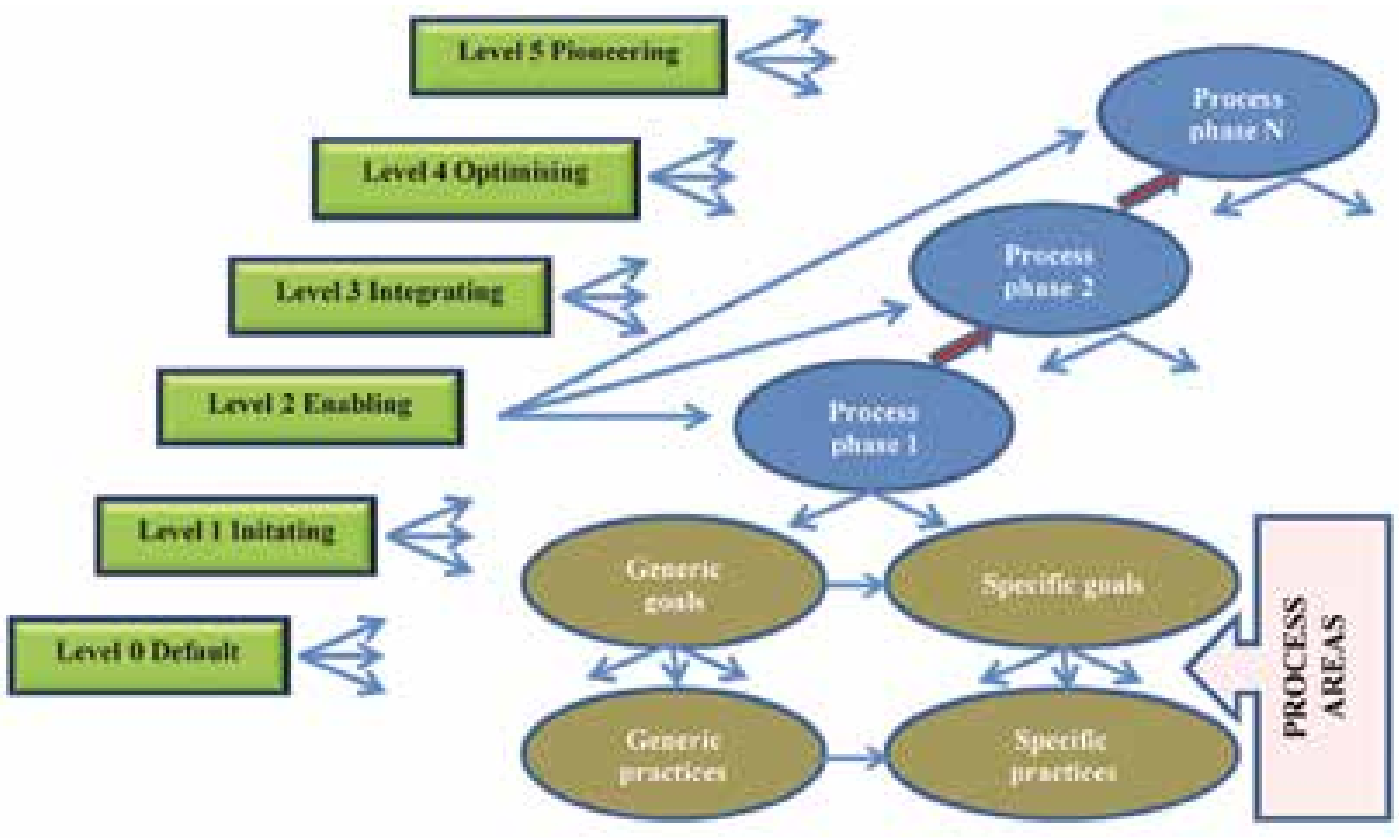

Source: Rutkowski, 2016, p. 213.

\section{The manager's role in the innovation process of a new product}

The immediate problem facing inexperienced managers is deciding where to start. In the staged representation, the solution is simple: you start with process areas at maturity level 2. If their implementation is successful, the next step is going to level 3, and then to levels 4 and 5, in that sequence. In other words, the new product development path is pre-defined and the only thing the organisation has to do is to follow it. Another issue affecting businesses without experience in process improvement programmes is taking corrective action on technological processes before appropriate foundation is built, such as the organisational project and process management framework. Based on experience, when no such foundation exists within the organisation and engineering processes are the first area of change, the usual outcome is that they are discarded and no longer used. The continuous representation, on the other hand, is a better choice for managers with a certain amount of experience in corrective action and for organisations that can identify strengths and weaknesses in their innovative processes, also in relation to the CMMI requirements. When deciding on a specific model representation, the organisation should take a look at the models and patterns it has followed in its earlier improvement activities. If they are more in line with the staged representation, perhaps there is no point in changing that and process improvements should be continued in small steps, 
incrementally, leading to higher maturity levels. However, if the earlier process development path had more in common with the continuous representation, it should be continued, too.

Before the organisation embarks on improving it, the new product development process (NPD) should be defined in terms of its required or optional phases/stages, necessary decision gates, information flow and coordination models across different organisational units, and resource allocation and colocation. When defining NPD, it is important to identify and determine the IT environment for the new product (geometric, configuration and process data; programme plans; product reference data). This task requires that a product data management system is in place storing new product configuration and project data, specifications, CAD-CAE-CAM tools, 3D, geometric models, engineering analysis models, repositories of drawings and photographs, testing procedures, manufacturing process plans, installation manuals, and audiovisual documentation [Bartkowiak, Rutkowski, 2016, pp. 113-122].

The product data management system provides continuous statistical control over NPD. It also reduces recorded process deviations from the adopted standards and measures, and enables corrective action to change the standard process. By comparing its adopted measures and standards with the objectives for the new product, the organisation can discover areas on which its project teams should focus their efforts and resources, and will also learn of any complications during the new product development. The continuous learning process helps to reduce deviations in NPD and provides project team members with a better insight into the process maturity level. With this knowledge, the project team can realistically determine project timeframe and implementation costs, increasing the odds of success for the new product.

The integrated new product development should be thought of as a continuous improvement process and there are few firms that can implement and use all of its major principles in a short time. ${ }^{3}$ Certain priorities of new product development may require that selected aspects of the integrated product development model are implemented and used.

First of all, a company's management should determine and have an understanding of the directions and rules of their firm's strategy (low cost, high quality, leadership in innovation and new technology applications), and then move on to estimate their competencies (weaknesses and strengths in the firm's resources in terms of their quality, quantity, and value). A firm's process improvement competencies can be estimated through a best practices-based comprehensive NPD review process. Best practices should be identified based on global research covering various firms and their strategies for the development of new products. Best practices in product development are classified into five categories: strategy, organisation, process, design optimisation, technology.

3 The foundations of the integrated new product development are these: understanding customers and their needs; integrating R\&D and new product development and investment processes with corporate development and marketing strategies; project/task teams; concurrent design of and support for the manufacturing process; digital product models; integrated CAD, CAE, and CAM tools; computer-based product and manufacturing process simulations; advanced design techniques which guarantee the high quality and reliability of new products; reduced design timeframe and costs; and continuous improvements to design and development processes. 
The diffusion of best practices is observable both within firms and across organisations. In-house diffusion involves adaptation and imitation of best practices by a firm's different organisational units, such as project teams. Communication channels are used to transmit and disseminate best practices among entities involved in new product development. This is done over a certain period of time and how fast best practices are diffused will depend on the ability of the entity concerned (a firm, organisational unit, or person) to learn, gather knowledge and use this knowledge in decision-making processes. The diffusion of best practices among firms describes how fast and to what extent such practices are adopted in an industry or within a group of similar businesses. The characteristics of a best practice will determine both the pace of its adaptation and its level.

Best practices which are strongly related to strategic competences (dimensions) in product development should be described as strategic NPD levers. For example, the following practices could be strategic levers that are actually and strongly related to the time-to-market metric/ dimension:

- New product development is only undertaken when there are sufficient resources.

- There is full commitment to the project and a task team is rapidly staffed (to get off to a good start).

- There is an emphasis on design re-use of modules, parts, cores, cells, part models, requirements documents, plans, technical documentation, simulation models, fixtures, tooling, etc. to minimise development cost and schedule.

- Customers are involved in new product development.

- Requirements are tightly managed to minimise changes that would require redesign. Consideration is given to new requirements in next generation products.

- Suppliers are involved early to collaborate and their ideas and suggestions are utilised to develop a design that is compatible with their manufacturing (process) capabilities.

- Product data management systems are deployed and used to control product data and streamline process workflows in order to speed up and control the flow of information.

- Electronic mock-ups and models are used.

The analysis of differences in performance ratings between best-practice sub-groups should reveal the highest priority areas which need improvements in NPD and may help to answer the following questions: how well the system does what it does, and how widespread a best practice is within the organisation, and how frequently it is used. ${ }^{4}$ It may be necessary to identify individual best practices with low performance ratings which are associated with each of NPD strategic dimensions. For management, this analysis would be the foundation to devise a competitive product development strategy and the NPD improvement and implementation plan.

4 Researchers into NPD best practices include: G. Cooper, K.M. Eisenhardt, B.N. Tabrizi, R. Calantone, J. Ettlie, K. Nobeoka, K. Crow, O. Hauptman, B.J. Zirger, J. Hartley, A. Griffin, I. Rutkowski, PDMA, ADL, BAH, Future State, DRM. 
A firm may use CMM/CMMI models in its new product development process to define appropriate goals and their priority, and to improve the process workflow by analysing its maturity, capabilities, and continuity. The CMM/CMMI models use general and specific practices. How the firm acts and behaves in this process is determined by various NPD areas and phases. Accordingly, product development practices should be interpreted and used after an in-depth consideration of other processes, too, whether those within the firm or existing in its surroundings.

Descriptive and prescriptive research has identified more than 270 best practices in the NPD process, categorised as strategy, process, organisation, design optimisation, and technology. The proposed Capability Maturity Model Integration (CMMI CMM/CMMI) has 141 best practices. The assumption is that most best practices represent collections of activities at different phases of the NPD process. The logical consequence, then, would be to use R.G. Cooper's Stage-Gate product innovation model to identify individual groups of best practices. The following best-practice categories were distinguished for further theoretical and empirical research, analysis and deliberation within that model: customer requirements, product strategy, concept generation, concept selection, concept design, detail design and redesign, manufacturing and (market) launch programmes, and product improvement. Using deduction and logical reasoning, these best-practice categories were then expanded to include practice groups that address new product goals and metrics, project management, process structuring and organisation, and technological leadership. ${ }^{5}$

\section{Summary}

Most of these best practices are universal and may be used in the development of many different products, regardless of the type and size of the firm. Some of them, however, are appropriate for the development of specific products only and in a specific marketing environment (e.g. service and maintenance practices have no use in the development of food products, whereas design practices involving series production are not relevant in the development of products used in satellite communications, such as geostationary satellites). How significant or relevant any given best practice is will therefore vary depending on the type of products offered by the firm and its operating environment. A collection of best practices consists of subgroups and is continually updated. New best practices are identified to replace the current ones that became standard practices. A significant number of best practices is represented by specific activities in the different phases of the NPD process.

5 For research purpose you can find two questionnaires of identified best practices at: http://nowyprodukt. ue.poznan.pl/index.php?page $=2$ 


\section{References}

1. Bartkowiak P., 2004. Rozwój zrównoważony jako jeden z kierunków restrukturyzacji przedsiębiorstw użyteczności publicznej. Przegląd Organizacji, no 6, pp. 22-25.

2. Bartkowiak P., Rutkowski I.P., 2016. The role of information in product innovation process and assortment management. LogForum Scientific Journal of Logistics, vol. 12, (2), pp. 113-122.

3. Capability Maturity Model Integration for Development. August 2006, Version 1.2. Technical Report CMU/SEI-2006-TR-008. Software Engineering Institute, Carnegie Mellon University.

4. Chrapko M., 2010. CMMI: Doskonalenie procesów w organizacji. Warszawa: Wydawnictwo Naukowe PWN, p. 265.

5. Cooper R.G., Edgett S.J., 2013, Benchmarking Best Practices Performance Results and the Role of Senior Management, Product Development Institute Inc., http://www.stage-gate.com/ downloads/wp/wp_32.pdf [access: 9.12.2017].

6. Cooper R.G., Edgett, S.J., 2008. Maximizing productivity in product innovation. Research Technology Management, March 1.

7. Cooper R.G., 1993. Winning at New Products, Reading Mass.: Addison-Wesley Publishing.

8. Cooper R.G., 2002. Winning at New Products. Accelerating the Process from Idea to Lunch, ed. 3 Reading Mass.: Adddison-Wesley Publishing Company.

9. Crawford C.M., 1979. New product failure rates - Facts and Fallacies. Research Management, September, pp. 9-13.

10. Griffin A., 1997. PDMA Research on New Product Development Practices: Updating trends and benchmarking best practices. Journal of Product Innovation Management, vol. 14(6), pp. 429-458.

11. Mu J., Ellen T., Gang P., Di Benedetto A., 2017. Strategic orientation and new product development performance: The role of networking capability and networking ability. Industrial Marketing Management, vol. 64, July, pp. 187-201.

12. Paulk M.C., Curtis B., Chrissis M.B., Weber C.C., 2011. Capability maturity model for software. Software Engineering Institute Technical Report no. CMU/SEI-2011-TR-24, sec. 2.3.

13. Pickshaus T., Kandt A., Hesse S., Fleischer K., Schmitt R., 2016. A Holistic Approach to Risk Oriented Lifecycle Engineering: Assessing Lifecycle Risks in Early Phases. Procedia CIRP, vol. 48, pp. 265-270.

14. Rutkowski I.P., 2016. Metody innowacji produktu. Macierzowo-sieciowe metody pomiaru dojrzałości procesu innowacji produktu. Poznań: Wydawnictwo Uniwersytetu Ekonomicznego w Poznaniu, p. 215.

15. Rutkowski I.P., 2007. Rozwój nowego produktu. Metody i uwarunkowania. Warszawa: PWE, pp. 77-92.

16. SCAMPI Upgrade Team. Appraisal Requirements for CMMI, 2011. Version 1.2 (ARC, V1.3) (CMU/SEI-2011-TR-001). Pittsburgh, PA: Software Engineering Institute, Carnegie Mellon University, April.

17. Skrzypek E., Hofman M., 2010. Zarzadzanie procesami w przedsiębiorstwie. Identyfikowanie, pomiar, usprawnianie. Warszawa: Wolters Kluwer, pp. 37-46. 
18. Stevens G.A. Burley J., 1997. 3000 raw Ideas = 1 Commercial Success. Research Technology Management, May-June, pp. 16-27.

19. The PDMA Glossary for New Product Development. Product Development \& Management Association 2012.

20. Trott P., 2011. Innovation Management and New Product Development, 5th ed. Harlow: Prentice Hall, Pearson Education.

21. Walker R., 2013. Winning with Risk Management (Financial Engineering and Risk Management). Hackensack, New York: World Scientific Publishing.

22. Wheelwright S.C., Clark C.B., 1992. Revolutionizing Product Development. New York: The Free Press. 
